\title{
Developing a Taxonomy Concerning Physical Existing Makerspaces in and Used by Schools
}

\author{
https://doi.org/10.3991/ijep.v11i2.17021 \\ Nanna Nora Sagbauer ( ${ }^{\varpi}$, Martin Ebner \\ Graz University of Technology, Graz, Austria \\ nanna.sagbauer@htl-hl.ac.at
}

\begin{abstract}
This systematic literature review addresses strongly on makerspaces in schools. An evaluation of literature about their status-quo shows qualitative and quantitative knowledge gaps in the relatively new field of makerspaces in and used by schools according to infrastructure, funding, and administration. A taxonomy concerning physical existing makerspaces in schools and used by schools including parameters like location, responsibilities, financing, instructors, users, time restrictions, and feasible maker activities is developed. Two different electronic journal databases, Institute of Electrical and Electronics Engineers (IEEE) and ScienceDirect, acted as source for this literature review. Most of this existing literature concentrates on the educational maker activities and only some feature additional information like the physical space, the financing or else. Nonetheless, these rare findings suggest four main categories of real-world makerspaces used for educational purposes in schools: External makerspaces, school makerspaces, open makerspaces located in schools, and temporary (Pop-up) makerspaces. Furthermore, we identified the need for investigations on the question of open makerspaces located in schools and the financial and organizational structure to operate them.
\end{abstract}

Keywords-Makerspace, literature review, taxonomy, maker education, maker movement, vocational school, primary school, secondary school

\section{Introduction}

Literacy used to be the ability to read and write but became so much more during the last century. When children leave school, they are supposed to have a certain level of literacy. Holbert wrote in the International Journal of Child-Computer Interaction: "Making is a literacy - a way of reading the world as a collection of resources and materials to be composed, repurposed, and rearranged. Making is 'what if?' and 'why not?'- of positioning oneself as having power - of taking responsibility for challenges and obstacles faced by oneself and one's community and enacting solutions." [20] Schön, Ebner and Kumar stated in 2014 that "Maker students are active learners, with a high need to explore, to discuss and to share experiences and ideas. [...] In general, the skills of creating and innovating can have a broad impact on students' lifelong learning and ultimately for education and society." [34] The importance of these 
competences was recognized by politics and so making is already emerging in some curricula $[13,35]$.

\subsection{The maker movement}

"The Maker Movement is a technological and creative evolution that has limitless implications for the world of education." [30] But how is this evolution implemented in schools? Do schools have makerspaces where maker education takes place? Is there a certain equipment which transfers a crafts room in school into a makerspace? Flores defines that a makerspace "provides access to real materials and tools that encourage students to tinker, repurpose, up-cycle, take things apart, and put them back together again." [14]

Papavlasopoulou et al. assessed the "Maker Movement and its emerging role in formal and informal education" [30] when they evaluated 43 empirical studies dated from 2011 to 2014 focusing on the making process and its effect on a successful learning experience. All but one studies took place in schools and the activities, duration, age of the participants and used materials were systematically documented. However, the physical space - the makerspace - where the activities took place, its infrastructure and machinery were not considered. Ford and Minshall identified in their 2019 article "Where and how 3D printing is used in teaching and education" a lack of literature on 3D printing technologies used in the education system [16]. As $3 \mathrm{D}$ printing is a characteristic technology in makerspaces [33] it also shows the need for further studies on makerspaces in educational contexts.

\subsection{Research questions}

This systematic literature review addresses strongly on makerspaces in schools. The main research questions inquire the existence and setup of (physical) makerspaces in and used by vocational schools, as well as primary and secondary schools. The evaluation of the literature shows knowledge gaps, qualitative and quantitative. It is important to have sufficient data concerning physical setup and infrastructure, financial support, and organization in the relatively new field of makerspaces in and used by schools. Successful development and realization of educational makerspaces rely on a sound scientific base concerning infrastructure, funding, and administrative organization. Therefore, additional investigation is needed. This work considers the following points of inquiry:

- Infrastructure: Existence, location, and setup of (physical) makerspaces in and used by vocational schools, as well as primary and secondary schools

- Financial structure: Possibilities for funding and economic development of makerspaces in and used by schools

- Organizational structure: Administration, accessibilities, responsibilities, instructors, and user groups of makerspaces in and used by schools 


\section{Search Strategy and Selection Criteria}

Two different electronic journal databases, Institute of Electrical and Electronics Engineers (IEEE) and ScienceDirect, acted as source for this literature review to achieve a very well-defined cross section of literature to outline the topic of makerspaces in and used by schools. These databases were chosen to highlight an engineering context according to a first focus on vocational schools, which had to be expanded on primary and secondary schools due to insufficient literature as an assumed consequence of a relatively small number of vocational schools. This research includes reviewed articles published in these databases up to June 1st, 2019. Only papers written in English were considered. The keywords used for literature extraction were "makerspace AND school"; "makerspace AND vocational AND education"; "makerspace AND primary AND education"; "makerspace AND secondary AND education".

The databases provided 67 hits (ScienceDirect 53; IEEE 14) whereof 31 proved to be valid according to the following selection criteria (valid: ScienceDirect 21, IEEE 10; invalid: ScienceDirect 32, IEEE 4). In a first selection all articles lacking educational context (e.g. medical prothesis research done by a School of Engineering with no other connection to school or university) where dismissed using only title and abstract. In a second selection stage the full texts were considered with the inclusion criteria of makerspace OR maker activity in primary OR secondary OR vocational school OR university and exclusion criteria of missing context to school AND makerspace (e.g. industrial makerspaces, ...).

\section{$3 \quad$ Findings}

Out of the 31 valid publications two address only virtual spaces for making activities like programming $[4,18]$ which will not be further discussed in this work. 22 papers mention physical makerspaces (actual physical spaces equipped for making activities). A majority of the presented literature examines the topics of this research only scarcely as Ferri et al. describe: "[The makerspace] is outfitted primarily with laser cutters, 3D printers, woodworking equipment, and other mechanical engineering focused machines" [2] and mainly documents the making activities. Nonetheless this information is used to develop a taxonomy concerning physical existing makerspaces in schools and used by schools. "No two makerspaces are the same. Each one is unique because it is designed with a specific purpose - to serve the individual and community where it is located." [29] We truly endorse this statement of Ensign and Leupold because it proves the difficulty to categorize makerspaces as a whole and still leads to an approach to classify makerspaces used in a school context with reference to the location. 


\subsection{Taxonomy concerning physical existing makerspaces in schools and used by schools}

The findings of literature suggest four main categories of real-world makerspaces used for educational purposes in and by schools:

1. External makerspaces

2. School makerspaces

3. Open makerspaces located in schools

4. Temporary (Pop-up) makerspaces

This research defines "external makerspaces" as rooms or spaces outside the school premises equipped for making activities, like commercial makerspaces, library makerspaces and similar. These external makerspaces hold the opportunity of cost since the school does not have to own the machinery and technological knowledge if trained experts are available. Another benefit of out of school environments is described by Dreessen and Schepers in 2019 by being low-stakes (non-evaluative), so "they provide opportunities for students to play or experiment with science and pursue new ideas or particularly motivating ones when there is interest." [9] In their work they write about a workshop in an external (commercial) makerspace where students and teachers started to realize an artefact which could be finished in class or at home. Martinich, Lehr et al. described a typical cooperation between a high school and a professional makerspace accompanied by a university. "Students work in the classroom on a Keystone Project, and complete fabrication of their ideas at the Tech Shop facilities. Students receive membership at Tech Shop and guidance on their projects." [23]

A hybrid form of external and school makerspace is featured by Compton et al. in 2017. The so called "MakerBus" is a school bus remodeled into a driving makerspace. Parked on school premises it serves as a temporary school makerspace. [7]

Hira et al. state in 2014 that makerspace inclusion in schools or classroom spaces "is a new idea that has surfaced in the academic community rather recently" [1]. Their definition of a makerspace is a very inclusive, as they define classroom makerspaces as places for students to come together and make things irrespective of the materials being used. They depict makerspaces not as the physical space but a type of learning environment which promotes the development of technological literacy. The literature suggests quite different concepts for school or even classroom makerspaces varying from computer labs with additional 3D printers [32] to fully equipped makerspaces with laser cutters, 3D printers, mechanical and electronic tools etc. [15, 20]. In this research school makerspaces are understood very broadly as physical spaces in a school building or used by schools equipped with the tools necessary for maker activities. Based on the literature findings a taxonomy concerning physical existing makerspaces in and used by schools was established as can be seen in Table 1: Taxonomy concerning physical existing makerspaces in and used by schools. 
Table 1. Taxonomy concerning physical existing makerspaces in and used by schools

\begin{tabular}{|c|c|c|c|c|c|c|c|}
\hline $\begin{array}{l}\text { Makerspace } \\
\text { taxonomy }\end{array}$ & Location & $\begin{array}{l}\text { Responsi- } \\
\text { bility }\end{array}$ & Funding & $\begin{array}{l}\text { Instruc- } \\
\text { tors }\end{array}$ & Users & $\begin{array}{c}\text { Time } \\
\text { re- } \\
\text { strictions }\end{array}$ & Activities \\
\hline \multirow{3}{*}{$\begin{array}{l}\text { School } \\
\text { makerspace }\end{array}$} & $\begin{array}{l}\text { Crafts } \\
\text { room }\end{array}$ & School & School & $\begin{array}{l}\text { Crafts } \\
\text { teachers }\end{array}$ & Students & $\begin{array}{l}\text { During } \\
\text { class }\end{array}$ & $\begin{array}{l}\text { Class pro- } \\
\text { jects, } \\
\text { guided } \\
\text { workshops }\end{array}$ \\
\hline & $\begin{array}{l}\text { Class- } \\
\text { room }\end{array}$ & School & School & Teachers & Students & $\begin{array}{l}\text { During } \\
\text { class }\end{array}$ & $\begin{array}{l}\text { Class pro- } \\
\text { jects, } \\
\text { guided } \\
\text { workshops }\end{array}$ \\
\hline & $\begin{array}{l}\text { School } \\
\text { library }\end{array}$ & School & School & $\begin{array}{l}\text { School } \\
\text { librarians }\end{array}$ & Students & $\begin{array}{l}\text { Opening } \\
\text { hours }\end{array}$ & $\begin{array}{l}\text { Class pro- } \\
\text { jects, private } \\
\text { projects, } \\
\text { guided } \\
\text { workshops } \\
\end{array}$ \\
\hline $\begin{array}{l}\text { Open } \\
\text { makerspace } \\
\text { located in } \\
\text { school }\end{array}$ & $\begin{array}{l}\text { Extra } \\
\text { physical } \\
\text { space in } \\
\text { school } \\
\text { building }\end{array}$ & $\begin{array}{l}\text { School or } \\
\text { operating } \\
\text { company or } \\
\text { association }\end{array}$ & $\begin{array}{l}\text { School } \\
\text { or oper- } \\
\text { ating } \\
\text { company } \\
\text { or asso- } \\
\text { ciation }\end{array}$ & $\begin{array}{l}\text { Teachers, } \\
\text { profes- } \\
\text { sionals }\end{array}$ & $\begin{array}{l}\text { Any- } \\
\text { body }\end{array}$ & $\begin{array}{l}\text { Opening } \\
\text { hours }\end{array}$ & $\begin{array}{l}\text { Class pro- } \\
\text { jects, private } \\
\text { projects, } \\
\text { professional } \\
\text { projects, } \\
\text { guided } \\
\text { workshops }\end{array}$ \\
\hline \multirow{3}{*}{$\begin{array}{l}\text { External } \\
\text { makerspace }\end{array}$} & Library & $\begin{array}{l}\text { Municipali- } \\
\text { ty }\end{array}$ & $\begin{array}{l}\text { Munici- } \\
\text { pality }\end{array}$ & Librarians & $\begin{array}{l}\text { Library } \\
\text { users }\end{array}$ & $\begin{array}{l}\text { Opening } \\
\text { hours }\end{array}$ & $\begin{array}{l}\text { Class pro- } \\
\text { jects, private } \\
\text { projects, } \\
\text { professional } \\
\text { projects, } \\
\text { guided } \\
\text { workshops } \\
\end{array}$ \\
\hline & $\begin{array}{l}\text { Universi- } \\
\text { ty }\end{array}$ & University & $\begin{array}{l}\text { Universi- } \\
\text { ty }\end{array}$ & $\begin{array}{l}\text { University } \\
\text { employees }\end{array}$ & $\begin{array}{l}\text { Stu- } \\
\text { dents, } \\
\text { employ- } \\
\text { ees }\end{array}$ & $\begin{array}{l}\text { Opening } \\
\text { hours }\end{array}$ & $\begin{array}{l}\text { Class pro- } \\
\text { jects, private } \\
\text { projects, } \\
\text { professional } \\
\text { projects, } \\
\text { guided } \\
\text { workshops } \\
\end{array}$ \\
\hline & $\begin{array}{l}\text { Profes- } \\
\text { sional } \\
\text { workshop }\end{array}$ & $\begin{array}{l}\text { Operating } \\
\text { company or } \\
\text { association }\end{array}$ & $\begin{array}{l}\text { Operat- } \\
\text { ing } \\
\text { company } \\
\text { or asso- } \\
\text { ciation }\end{array}$ & $\begin{array}{l}\text { Profes- } \\
\text { sionals }\end{array}$ & $\begin{array}{l}\text { Any- } \\
\text { body }\end{array}$ & $\begin{array}{l}\text { Opening } \\
\text { hours }\end{array}$ & $\begin{array}{l}\text { Class pro- } \\
\text { jects, private } \\
\text { projects, } \\
\text { professional } \\
\text { projects, } \\
\text { guided } \\
\text { workshops } \\
\end{array}$ \\
\hline $\begin{array}{l}\text { Temporary } \\
\text { (Pop-up) } \\
\text { makerspace }\end{array}$ & Anywhere & $\begin{array}{l}\text { Operating } \\
\text { company or } \\
\text { association }\end{array}$ & $\begin{array}{l}\text { Operat- } \\
\text { ing } \\
\text { company } \\
\text { or asso- } \\
\text { ciation, } \\
\text { anybody } \\
\end{array}$ & Anybody & $\begin{array}{l}\text { Any- } \\
\text { body }\end{array}$ & $\begin{array}{l}\text { Opening } \\
\text { hours }\end{array}$ & $\begin{array}{l}\text { Class pro- } \\
\text { jects, private } \\
\text { projects, } \\
\text { professional } \\
\text { projects, } \\
\text { guided } \\
\text { workshops } \\
\end{array}$ \\
\hline
\end{tabular}

Six of nine identified publications on school makerspaces did not specify the physical space where the making activity took place but concentrated on other aspects [1, $6,13,16,21,35]$. Chu et al. considered the "Maker experience in a formal education- 
al context"[6] as very complex regarding institutional structures, environmental factors and social dynamics whereas Hsu in her work on tourism education described the role of lecturers in makerspace education with the words "co-creators of knowledge alongside students"[21]. Some elementary and secondary schools in Canada have developed makerspaces which are usually located in classrooms or school libraries [29]. Sweden is currently running a large-scale national testbed on makerspaces in schools. More than 30 formal actors are involved and explore the idea of recasting school's craft environments into makerspaces [13]. Technology Comprehension is the name of a new subject in Denmark's curricula with a very strong makerspace affiliation. It includes "computing skills, design and development of a digital solutions and the evaluation of these solutions, including a socio-political context" [35] but does not define the physical teaching space. Saorín et al. name makerspaces of the High School of Sierra Vista de La Puente, in California, and of the high school of Monticello, in Charlottesville, Virginia, but do not to give further information to answer the research questions in detail. They state that these makerspaces "contribute to the decrease of school absenteeism and the improvement in the performance of subjects such as mathematics or the fostering of a greater interest in Science and Engineering degrees." [33] Further they present the 2008 launched project "FabLab@School" by Stanford University which started the building of makerspaces in primary and secondary schools with the example of MC2STEM High School of Ohio and a project called "MakerSpace" with funding of DARPA (Defense Advanced Research Projects Agency).

This was the only information on the funding of all discussed maker spaces. Though, Hira et al. stated the cost, including additional equipment and other supplies, as a possible barrier for making activities in school. [1] Ho et al. underline the importance that "economic support should not solely be derived from user fees, which may be perceived by users as a loss of control and autonomy over their project. Practitioners should seek economic support from a variety of sources as appropriate, including user fees, corporate and community donations, and external grants." [19] Industry-school cooperation in makerspaces could be used to acquire the necessary funds. It can also address another issue stated by Chen, Hoople et al. "What is considered 'engineering expertise' in academia may not align with what is considered expertise in industry." [5]

\subsection{Maker culture, interdisciplinary and openness}

Despite the obvious question of funding, the attention of previous work was concentrated on the maker culture which provides students communication, guidance, and support. [36] Questioning, observation and giving instruction were identified by Chu et al. as the main ways by which potential opportunities for learning happen. According to their work the maker experience "amplified the likelihood of a particular behavior resulting in some form of learning." [6] Another aspect of making presented in the literature is the trial and error process. "Failure, or something not working out as expected, is often a part of the development process" [28] and so an integral part of making. Non-functioning artefacts are usually not intended in assessed student 
work and will probably be graded poorly still they are inevitable for an innovative development process. Cornejo et. Al understand " 'failure' as something to be learned from and [...] an important step towards continuous improvement."[8] These findings suggest that evaluation and grading of students in makerspaces are also aspects to consider when looking at makerspaces in educational contexts and its effects on different disciplines however not the focal point of this work. Ercan, Sale and Kristian observed that "certain key features such as interdisciplinary, collaborative active and experiential learning, and authentic assessment for learning" develop the "engineering as well as communication and teamwork skills of students [...] significantly".[11] The scope of subjects introducing making activities is wide, even using a makerspace for ocean technology education [27] was investigated. Another study found "that students who use the space either for class projects or for their own personal projects had significantly higher inmajor GPAs than students who did not use the space" [10]. So, the effect of making with regards to the students' grades and academic success was examined there. The fact that students say "I get to do things on my own" [16] in formal education seems like an important learning motivation.

Fox described the making process in school makerspaces to involve "most structure and least agency" compared to other making environments [17], which seems to be owed to the necessity of teachers to grade the students' work. Ramey and Stevens pronounce the makerspace a "creative scene", where "education is crossorganizational, inter-spatial and interdisciplinary. It breaks the closed boundaries in order to truly realize the integration of innovation" [31] whereas Tomko et al. 2017 identify the flexibility and openness of makerspaces as keys "to how the students make sense of their instrumental and relational value". [25] There are several characteristics of a makerspace that can be "open", like the building space, the used softand hardware, the accessibility, or the user group. The finding that "Knowledge creation and sharing spaces transcend organizational boundaries"[3] and the stated fact that "Most activities could not be undertaken with the resources available to an individual or when working alone" [29] give reason to think that opening makerspaces in schools for divergent user groups including students and teachers as well as other persons interested in making artefacts would be beneficial. Open makerspaces located in schools show way to bring making into schools and tend to stimulate a very diverse audience as "Digital fabrication technologies should foster curiosity, engagement and motivation for learning among students of all ages." [22] As "The Maker community of practice is brought together by a common interest in Making, have a shared knowledge in how to Make things, and regularly learn techniques from others in the Maker community" [26] divergent agents in a makerspace enrich the making environment with multiple ideas, techniques and knowledge and so the makerspaces "increase the chance that makers will discover others with similar project interests" and may be "leading to potential business partnerships when commercial opportunities arise." [3] These business opportunities are important assets for last year students in vocational schools, high schools, and universities. The commercial aspect and the openness are opposing qualities of makerspaces as identified by Langley et al. "It seems that the presence of conditional sharing is important when one tries to further 
commercialize, while the presence of unconditional sharing is important to keep the sharing and community spirit alive for attracting new participants." [24]

\subsection{The development trajectory of a school makerspace}

The development trajectory of a school makerspaces according to Langley et al. (see Fig. 1: Langley, Zirngiebl et al. 2017 - Trajectories to reconcile sharing.jpg [24] ) is clearly the path of the so called "Dependent social idealist" as no commercial aspects are included whereas the open makerspace located in schools could also take the turn and become a "Social enterprise" which would be preferable, because the makerspace would not stress school budget. Unfortunately, the literature used in this research did not present any open makerspaces located in schools so far. The only open makerspaces in educational facilities were installed in numerous universities in the last couple of years. $[2,10,25,27,31,33,36]$ The funding of these makerspace did not present itself in the used literature.

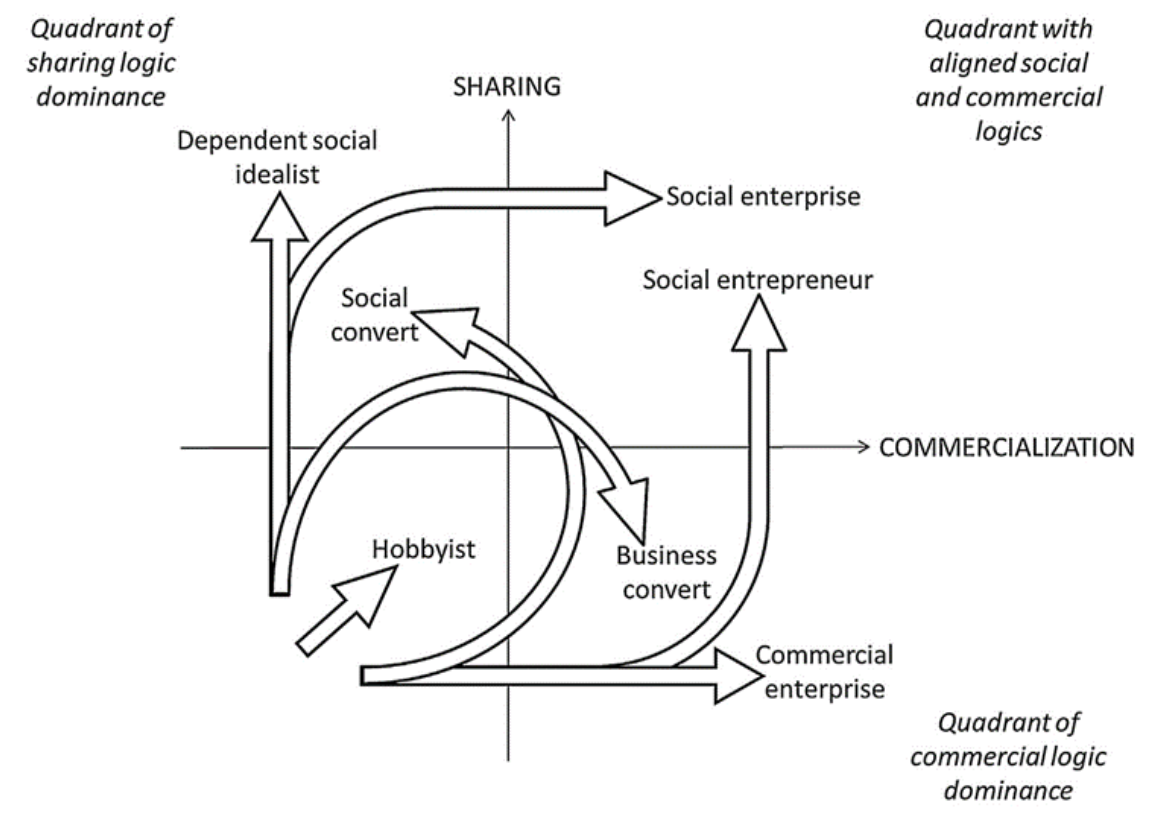

Fig. 1. Development trajectories of maker initiatives in terms of commercialization logics according to Langley, Zirngiebl et al. [24]

\section{$4 \quad$ Study Limitations}

Makerspaces in schools as well as maker education are relatively new fields of scientific research as the earliest relevant article in the considered literature dates to 2014. The number of articles on makerspaces and schools peaked to 12 per year in 2017 (compare to Fig. 2: Number of articles on makerspaces and schools). According 
to these numbers there are five possible conclusions: (i) Makerspaces in and used by schools are very rare; (ii) Makerspaces in and used by schools are rarely the subject of scientific research; (iii) Makerspaces in and used by schools are a relatively new field of research and so their appearance in the literature is delayed to their appearance (iv) The literature on ScienceDirect and IEEE is not representative and other databases should be considered as well as follow up literature; (v) Any combination of the above.

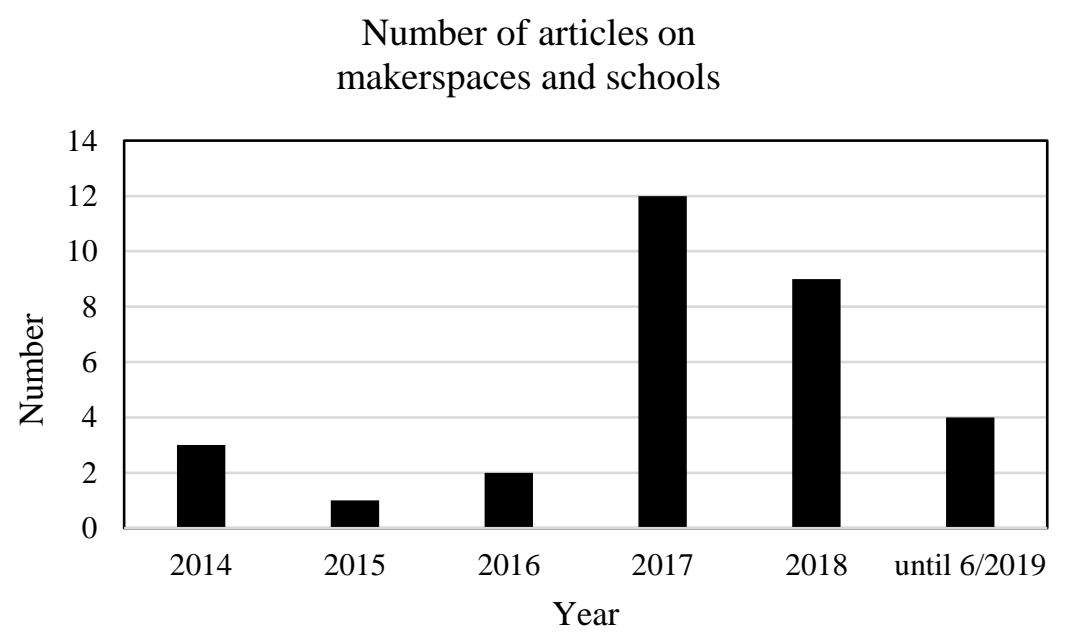

Fig. 2. Number of articles on makerspaces and schools

Further limitation to the literature were the publication language English and the demand of being reviewed. These requirements might not cover papers and reports written by primary, secondary, and vocational teachers or educational staff in different counties with diverse native languages.

\section{Conclusion}

Lande and Jordan predicted in 2014 that "the learning-focused use of making and tinkering" [26] may come forward in science and engineering classes. What they did not know, is that making did not limit itself on these subjects. In this research a lot of examples of using making activities were presented in very different fields as they offer "different perspective in the learning process, as it gives learners the opportunity to have control over their own knowledge, instead of being passive recipients." [30] Even though makerspaces in and used by schools are a relatively new development, the research already presents some valuable data (compare Figure 2: Number of articles on makerspaces and schools) on the infrastructure, which we used to deduce a taxonomy concerning physical existing makerspaces in and used by schools (see 
Table 1). Four main categories were identified: External makerspaces, school makerspaces, open makerspaces located in schools, and temporary (Pop-up) makerspaces. According to the research questions the taxonomy examines infrastructure, financial structure, and organizational structure of makerspaces in and used by schools featuring location, responsibility, funding, instructors, users, time restrictions, and activities. This research also shows the diversity of making in schools and its interdisciplinarity. The openness of a makerspace seems to be an important factor for informal knowledge transfer and potential (business) partnerships enriching the school environment. To operate a makerspace in school as a "Social enterprise" [24] is identified to be preferable (as discussed in 3.3 The development trajectory of a school makerspace). Therefore, especially the category of open makerspaces located in schools seems in need of further research.

\section{References}

[1] A. Hira, C. H. Joslyn, and M. M. Hynes, Eds. 2014. Classroom makerspaces: Identifying the opportunities and challenges. 2014 IEEE Frontiers in Education Conference (FIE) Proceedings. https://doi.org/10.1109/fie.2014.7044263

[2] B. Ferri, K. Pham, J. Steinberg, W. Williams, and K. Ferri, Eds. 2017. Practical skills and design: A maker course for ECE students. 2017 IEEE Frontiers in Education Conference (FIE). https://doi.org/10.1109/fie.2017.8190477

[3] R. E. Browder, H. E. Aldrich, and S. W. Bradley, 2019. The emergence of the maker movement: Implications for entrepreneurship research. Journal of Business Venturing 34, 3, 459-476. https://doi.org/10.1016/j.jbusvent.2019.01.005

[4] C. Chytas, I. Diethelm, and A. Tsilingiris, Eds. 2018. Learning programming through design: An analysis of parametric design projects in digital fabrication labs and an online makerspace. 2018 IEEE Global Engineering Education Conference (EDUCON). https://doi.org/10.1109/educon.2018.8363478

[5] D. A. Chen, G. D. Hoople, N. Ledwith, E. Burlingame, S. D. Bush, and G. E. Scott, 2020. Exploring Faculty and Student Frameworks for Engineering Knowledge Using an Online Card Sorting Platform. Int. J. Eng. Ped. 10, 1, 62. https://doi.org/10.3991/ijep.v10i1.11336

[6] S. L. Chu, G. Angello, M. Saenz, and F. Quek, 2017. Fun in Making: Understanding the experience of fun and learning through curriculum-based Making in the elementary school classroom. Entertainment Computing 18, 31-40. https://doi.org/10.1016 /j.entcom.2016.08.007

[7] M. E. Compton, K. Martin, and R. Hunt, 2017. Where do we go from here? Innovative technologies and heritage engagement with the MakerBus. Digital Applications in Archaeology and Cultural Heritage 6, 49-53. https://doi.org/10.1016/j.daach.2017.04.002

[8] M. G. Cornejo, B. O'Hara, F. Tarazona-Vasquez, F. Barrios, and M. Power, 2018. Moray: Bridging an Ancient Culture of Innovation with Emerging Pedagogies in Engineering. Int. J. Eng. Ped. 8, 4, 43. https://doi.org/10.3991/ijep.v8i4.8139

[9] K. Dreessen, and S. Schepers, 2019. Foregrounding backstage activities for engaging children in a FabLab for STEM education. International Journal of Child-Computer Interaction. https://doi.org/10.1016/j.ijcci.2019.02.001

[10] E. C. Hilton, R. L. Nagel, and J. S. Linsey, Eds. 2018. Makerspace Involvement and Academic Success in Mechanical Engineering. 2018 IEEE Frontiers in Education Conference (FIE). https://doi.org/10.1109/fie.2018.8658875 
[11] F. Ercan, D. Sale, and N. Kristian, 2016. Innovative Curriculum to Enhance the Learning Experience of Electrical and Mechanical Engineering Students. Int. J. Eng. Ped. 6, 3, 37. https://doi.org/10.3991/ijep.v6i3.5765

[12] M. F. Ercan, 2013. Integration in Engineering Education: A Trial Run. Int. J. Eng. Ped. 3, 3,61

[13] E. Eriksson, C. Heath, P. Ljungstrand, and P. Parnes, 2018. Makerspace in schoolConsiderations from a large-scale national testbed. International Journal of ChildComputer Interaction 16, 9-15. https://doi.org/10.1016/j.ijcci.2017.10.001

[14] M. Esselman, B. Gardner, and M. Gillespie, 2017. Operation Breakthrough in 2017 Builds on the Past. Current Problems in Pediatric and Adolescent Health Care 47, 9, 235-237. https://doi.org/10.1016/j.cppeds.2017.07.011

[15] C. Flores, 2018. Problem-based science, a constructionist approach to science literacy in middle school. International Journal of Child-Computer Interaction 16, 25-30. https://doi.org/10.1016/j.ijcci.2017.11.001

[16] S. Ford, and T. Minshall, 2019. Invited review article: Where and how 3D printing is used in teaching and education. Additive Manufacturing 25, 131-150. https://doi.org/10.1016 /j.addma.2018.10.028

[17] S. Fox, 2017. Mass imagineering: Combining human imagination and automated engineering from early education to digital afterlife. Technology in Society 51, 163-171. https://doi.org/10.1016/j.techsoc.2017.09.001

[18] M. N. Giannakos, and L. Jaccheri, 2018. From players to makers: An empirical examination of factors that affect creative game development. International Journal of ChildComputer Interaction 18, 27-36. https://doi.org/10.1016/j.ijcci.2018.06.002

[19] S.-Y. Han, J. Yoo, H. Zo, and A. P. Ciganek, 2017. Understanding makerspace continuance: A self-determination perspective. Telematics and Informatics 34, 4, 184-195. https://doi.org/10.1016/j.tele.2017.02.003

[20] N. Holbert, 2016. Leveraging cultural values and "ways of knowing" to increase diversity in maker activities. International Journal of Child-Computer Interaction 9-10, 33-39. https://doi.org/10.1016/j.ijcci.2016.10.002

[21] C. H. C. Hsu, 2018. Tourism education on and beyond the horizon. Tourism Management Perspectives 25, 181-183. https://doi.org/10.1016/j.tmp.2017.11.022

[22] O. S. Iversen, R. C. Smith, P. Blikstein, E.-S. Katterfeldt, and J. C. Read, 2015. Digital fabrication in education: Expanding the research towards design and reflective practices. International Journal of Child-Computer Interaction 5, 1-2. https://doi.org/10.1016 /j.ijcci.2016.01.001

[23] L. P. Martinich, T. Lehr, and D. Sangam, Eds. 2014. Make the World a better place: An association-industry-academia partnership. 2014 IEEE Integrated STEM Education Conference. https://doi.org/10.1109/isecon.2014.6891034

[24] D. J. Langley, M. Zirngiebl, J. Sbeih, and B. Devoldere, 2017. Trajectories to reconcile sharing and commercialization in the maker movement. Business Horizons 60, 6, 783794. https://doi.org/10.1016/j.bushor.2017.07.005

[25] M. E. Tomko, J. Linsey, R. Nagel, and M. W. Alemán, Eds. 2017. Exploring meaningmaking and innovation in makerspaces: An ethnographic study of student and faculty perspectives. 2017 IEEE Frontiers in Education Conference (FIE). https://doi.org/10.1109 /fie.2017.8190580

[26] M. Lande and S. Jordan, Eds. 2014. Making it together, locally: A making community learning ecology in the Southwest USA. 2014 IEEE Frontiers in Education Conference (FIE) Proceedings. https://doi.org/10.1109/fie.2014.7044394

[27] M. Saul, Ed. 2016. Exploration and remote instrumentation by Students (ERIS): Video documentation in undergraduate ocean technology education. OCEANS 2016 MTS/IEEE Monterey. https://doi.org/10.1109/oceans.2016.7761302 
[28] A. V. Maltese, A. Simpson, and A. Anderson, 2018. Failing to learn: The impact of failures during making activities. Thinking Skills and Creativity 30, 116-124. https://doi.org/10.1016/j.tsc.2018.01.003

[29] P. C. Ensign and P. Leupold, Eds. 2018. Grassroots Opportunities for Innovation, Technology, and Entrepreneurship: Makerspaces in Non-Urban Communities. 2018 Portland International Conference on Management of Engineering and Technology (PICMET). https://doi.org/10.23919/picmet.2018.8481850

[30] S. Papavlasopoulou, M. N. Giannakos, and L. Jaccheri, 2017. Empirical studies on the Maker Movement, a promising approach to learning: A literature review. Entertainment Computing 18, 57-78. https://doi.org/10.1016/j.entcom.2016.09.002

[31] Q. Zhan and M. Yang, Eds. 2017. A model of maker education in China universities by smart technologies: The perspective of innovation ecosystem. 2017 IEEE 2nd International Conference on Big Data Analysis (ICBDA). https://doi.org/10.1109/icbda.2017.8078711

[32] K. E. Ramey, and R. Stevens, 2018. Interest development and learning in choice-based, inschool, making activities: The case of a 3D printer. Learning, Culture and Social Interaction. https://doi.org/10.1016/j.lcsi.2018.11.009

[33] J. L. Saorín, D. Melian-Díaz, A. Bonnet, C. Carbonell Carrera, C. Meier, and J. de. La Torre-Cantero, 2017. Makerspace teaching-learning environment to enhance creative competence in engineering students. Thinking Skills and Creativity 23, 188-198. https://doi.org/10.1016/j.tsc.2017.01.004

[34] S. Schön, M. Ebner, M., and S. Kumar, 2014. The Maker Movement. Implications of new digital gadgets, fabrication tools and spaces for creative learning and teaching. eLearning Papers 39, 14-25.

[35] A. Tuhkala, M.-L. Wagner, O.S. Iversen, T. and Kärkkäinen, 2019. Technology Comprehension - Combining computing, design, and societal reflection as a national subject. International Journal of Child-Computer Interaction. https://doi.org/10.1016 /j.ijcci.2019.03.004

[36] Y. Wang, W. Zhou, and L. Lu, Eds. 2017. Multi-dimensional computer basic education practice and research. 2017 12th International Conference on Computer Science and Education (ICCSE). https://doi.org/10.1109/iccse.2017.8085588

[37] A. Brahms, "Representation error for real numbers in binary computer arithmetic," IEEE Computer Group Repository, Paper R-67-85.

\section{Authors}

Nanna Nora Sagbauer is a Ph.D. student at the doctoral school of Computer Science at Graz University of Technology. She is researching the field of makerspaces for educational purposes. Additionally, she teaches electrical engineering at the Technical Collage Hollabrunn.

Martin Ebner is the head of Department Educational Technology at Graz University of Technology and therefore responsible for all university wide e-learning activities. He holds an Adjunct Prof. on media informatics (research area: educational technology) and his research focuses strongly on seamless learning, learning analytics, open educational resources, maker education and computer science for children. More info see: http://martinebner.at

Article submitted 2020-07-14. Resubmitted 2020-11-25. Final acceptance 2020-12-23. Final version published as submitted by the authors. 